\title{
Estimating the health and economic effects of the voluntary sodium reduction targets in Brazil: microsimulation analysis
}

Eduardo Augusto Fernandes Nilson ${ }^{1 *} \mathbb{D}$, Jonathan Pearson-Stuttard², Brendan Collins ${ }^{3}$, Maria Guzman-Castillo ${ }^{3}$, Simon Capewell ${ }^{3}$, Martin O'Flaherty ${ }^{3}$, Patrícia Constante Jaime ${ }^{1}$ and Chris Kypridemos ${ }^{3}$

\begin{abstract}
Background: Excessive sodium consumption is one of the leading dietary risk factors for non-communicable diseases, including cardiovascular disease (CVD), mediated by high blood pressure. Brazil has implemented voluntary sodium reduction targets with food industries since 2011. This study aimed to analyse the potential health and economic impact of these sodium reduction targets in Brazil from 2013 to 2032.
\end{abstract}

Methods: We developed a microsimulation of a close-to-reality synthetic population (IMPACT $T_{N C D-B R}$ ) to evaluate the potential health benefits of setting voluntary upper limits for sodium content as part of the Brazilian government strategy. The model estimates CVD deaths and cases prevented or postponed, and disease treatment costs. Model inputs were informed by the 2013 National Health Survey, the 2008-2009 Household Budget Survey, and highquality meta-analyses, assuming that all individuals were exposed to the policy proportionally to their sodium intake from processed food. Costs included costs of the National Health System on CVD treatment and informal care costs. The primary outcome measures of the model are cardiovascular disease cases and deaths prevented or postponed over 20 years (2013-2032), stratified by age and sex.

Results: The study found that the application of the Brazilian voluntary sodium targets for packaged foods between 2013 and 2032 could prevent or postpone approximately 110,000 CVD cases (95\% uncertainty intervals (UI): 28,000 to 260,000 ) among men and 70,000 cases among women (95\% UI: 16,000 to 170,000 ), and also prevent or postpone approximately 2600 CVD deaths (95\% UI: - 1000 to 11,000), 55\% in men. The policy could also produce a net cost saving of approximately US\$220 million (95\% UI: US\$ 54 to 520 million) in medical costs to the Brazilian National Health System for the treatment of CHD and stroke and save approximately US\$ 71 million (95\% UI: US\$ 17 to170 million) in informal costs.

Conclusion: Brazilian voluntary sodium targets could generate substantial health and economic impacts. The reduction in sodium intake that was likely achieved from the voluntary targets indicates that sodium reduction in Brazil must go further and faster to achieve the national and World Health Organization goals for sodium intake.

Keywords: Sodium, Sodium reduction, Sodium targets, Health economics, Cardiovascular disease, Hypertension, Food policy, Public health, Global health

\footnotetext{
* Correspondence: edunilson@gmail.com

${ }^{1}$ Center for Epidemiological Research in Nutrition and Public Health, University of São Paulo, São Paulo, Brazil

Full list of author information is available at the end of the article
}

(C) The Author(s). 2021 Open Access This article is licensed under a Creative Commons Attribution 4.0 International License, which permits use, sharing, adaptation, distribution and reproduction in any medium or format, as long as you give appropriate credit to the original author(s) and the source, provide a link to the Creative Commons licence, and indicate if changes were made. The images or other third party material in this article are included in the article's Creative Commons licence, unless indicated otherwise in a credit line to the material. If material is not included in the article's Creative Commons licence and your intended use is not permitted by statutory regulation or exceeds the permitted use, you will need to obtain permission directly from the copyright holder. To view a copy of this licence, visit http://creativecommons.org/licenses/by/4.0/ The Creative Commons Public Domain Dedication waiver (http://creativecommons.org/publicdomain/zero/1.0/) applies to the data made available in this article, unless otherwise stated in a credit line to the data. 


\section{Background}

Non-communicable diseases (NCDs) are a global health problem, and unhealthy diets are among its leading drivers. Among dietary risk factors, high sodium intake was the leading cause of morbidity and mortality worldwide, accounting for some 3 million deaths and 70 million disability-adjusted life-years (DALYs) [1]. In Brazil, NCDs are responsible for $75 \%$ of all deaths, and cardiovascular disease (CVD) is the most frequent cause of death among NCDs [2]. CVD represents the most significant disease burden attributable to high sodium intake, and much of this risk is mediated through blood pressure increase [3].

The average daily sodium consumption in Brazil is approximately double the World Health Organization (WHO) [4] recommended maximum limit of 2g [5]. Thus, over 27,000 deaths from coronary heart disease (CHD) and stroke could be prevented or postponed every year if Brazilians consumed, on average, less than $2 \mathrm{~g} /$ day sodium [6]. However, unlike many high-income countries with "Western" type diets, only about 35\% of Brazilians' dietary sodium comes from industrialised foods and salt-based condiments, whereas over 55\% comes from added table salt [7-9]. Sodium reduction policies in Brazil have therefore incorporated a set of strategies. These include health education campaigns targeted to the table salt added to foods and meals [10], and since 2011, food reformulation strategies aimed at reducing the sodium content of processed and ultraprocessed products, including condiments, through voluntary upper limits for sodium content in priority food categories [11]. From 2011 to 2017, all food categories have reduced their upper limits of sodium and most have reduced their average sodium content, from 8 to $34 \%$ [12].

The objective of this study was to quantify the potential health and economic impacts of voluntary sodium reformulation in Brazil.

\section{Methods}

We have developed IMPACT ${ }_{\text {NCD-BR }}$, a new microsimulation for Brazil using available local data, building on our previous experience in sodium modelling [13-16]. We used IMPACT ${ }_{N C D-B R}$ to assess the potential health and economic effects of the voluntary targets for sodium content in processed foods in Brazil over 20 years (2013-2032).

We simulated the long-term impact of reducing the sodium content of processed and ultra-processed foods through the national voluntary targets from 2013 to 2017, compared to a "no intervention" baseline scenario. We assumed that sodium reduction in foods was achieved from 2013 through 2017, that only industries officially committed to the voluntary targets would reduce the sodium content of their products (corresponding to $70 \%$ of the Brazilian market share), and that the sodium content and target compliance by industries from 2017 onwards [12] would not change. We further assumed that, given the extent of the reformulation, all individuals were exposed to the policy proportionally to their sodium intake from processed food.

\section{The IMPACT NCD-BR $_{\text {model }}$}

IMPACT $_{\mathrm{NCD}-\mathrm{BR}}$ is a discrete-time stochastic, dynamic, microsimulation model based on the simulated adult life course of a close-to-reality open cohort of synthetic individuals under different policy scenarios, considering the population heterogeneity and the lag times between exposures and outcomes. The data sources to the model are presented in Table 1, and the model inputs, structure, and key assumptions are detailed in Supplementary Materials Appendix.

The model is designed first to run the no intervention scenario, simulating the life courses of the synthetic individuals and recording sodium consumption, systolic blood pressure, first cardiovascular episode, and death (from CVD or any other cause). Then, it simulates the life courses of the same synthetic population under the intervention scenario (in this case, food reformulation through the national voluntary sodium targets) and records its outcomes.

The close-to-reality population built in the model mirrors the Brazilian national population structure by age and sex [18]. It includes data from the National Health Survey (Pesquisa Nacional de Saúde-PNS 2013) [22] and the National Household Budget Survey (Pesquisa de Orçamentos Familiares-POF 2008-2009) [20, 21] regarding sodium and systolic blood pressure (SBP) exposure.

\section{Microsimulation model structure}

Figure 1 shows a simplified structure of the IMPACT $_{\mathrm{NCD} \text {-BR }}$ model. The model tracks individuallevel sodium consumption, considering the different sources of dietary sodium, its impact on SBP, and the consequent risk of developing $\mathrm{CHD}$, stroke, and death from these or any other cause. IMPACT $\mathrm{T}_{\mathrm{NCD}-\mathrm{BR}}$ is calibrated to forecasts of CHD, stroke, and any-other-cause mortality for the whole Brazilian population from 2013 to 2032. The results are presented for adults aged 30 to 79 years within the simulation horizon of 20 years.

For this, the model draws the traits of the synthetic individuals from conditional distributions, projects the sodium intake into the future, and uses the projections to evolve the traits of the synthetic individuals over time. We used PNS 2013 for the SBP projections (assuming SBP remains constant over time for all age and sex groups) and POF 2008-2009 for the sodium intake projections [20-22]. 
Table 1 IMPACT ${ }_{\text {NCD-BR }}$ data sources

\begin{tabular}{|c|c|c|c|c|}
\hline Parameter & Outcome & Details & Comments & Source \\
\hline $\begin{array}{l}\text { Population size } \\
\text { estimates }\end{array}$ & Population & $\begin{array}{l}\text { Brazilian Institute of } \\
\text { Geography and Statistics } \\
\text { (IBGE) }\end{array}$ & Stratified by age and sex & $\begin{array}{l}\text { Brazilian Institute of } \\
\text { Geography and } \\
\text { Statistics (IBGE) [17] }\end{array}$ \\
\hline $\begin{array}{l}\text { Population } \\
\text { projections }\end{array}$ & Population & $\begin{array}{l}\text { 2010-2060 Brazil population } \\
\text { projections produced by IBGE }\end{array}$ & Stratified by year, age and sex & $\begin{array}{l}\text { Brazilian Institute of } \\
\text { Geography and } \\
\text { Statistics (IBGE) [18] }\end{array}$ \\
\hline Mortality & $\begin{array}{l}\text { Deaths from CHD, stroke, } \\
\text { and any other non- } \\
\text { modelled causes }\end{array}$ & $\begin{array}{l}\text { Underlying cause of death } \\
2000-2016\end{array}$ & Stratified by year, age and sex & $\begin{array}{l}\text { National Mortality } \\
\text { Information System } \\
\text { (SIM/SUS) [19] }\end{array}$ \\
\hline Sodium exposure & Exposure of individuals & $\begin{array}{l}\text { National Household Budgetary } \\
\text { Survey }\end{array}$ & Anonymised, individual-level dataset & $\begin{array}{l}\text { IBGE - National } \\
\text { Household } \\
\text { Budgetary Survey } \\
\text { (POF) 2008-2009 [20, } \\
\text { 21] }\end{array}$ \\
\hline $\begin{array}{l}\text { Systolic blood } \\
\text { pressure } \\
\text { exposure }\end{array}$ & Exposure of individuals & National Health Survey & Anonymised, individual-level dataset & $\begin{array}{l}\text { IBGE - National } \\
\text { Health Survey (PNS) } \\
2013 \text { [22] }\end{array}$ \\
\hline $\begin{array}{l}\text { Effect of sodium } \\
\text { consumption on }\end{array}$ & Systolic blood pressure & $\begin{array}{l}\text { Meta-analysis/meta-regression } \\
\text { of } 103 \text { trials }\end{array}$ & $\begin{array}{l}\text { Only trials with duration }>7 \text { days were } \\
\text { analysed }\end{array}$ & Mozaffarian et al. [3] \\
\hline
\end{tabular}

pressure

Reference level of sodium consumption

Ideal sodium consumption below which no excess risk was considered to occur

Relative risk for systolic blood pressure

CHD and stroke incidence (ICD-10: I20-I25 and 160169)

Mortality from any cause excluding CHD and stroke

Reference level of systolic blood pressure

Ideal systolic blood pressure below which no excess risk was considered to occur

Disease costs
Evidence from ecological studies, randomised trials, and meta-analyses of prospective cohort studies
Intake levels associated with the lowest risk ranged from 614 to $2391 \mathrm{mg} / \mathrm{day}$; in large, well-controlled randomised feeding trials, the lowest tested intake for which blood pressure reductions were clearly documented was $1500 \mathrm{mg} /$ day

Pooled analysis of 2 individuallevel meta-analyses

Individual-level meta-analysis of 48 prospective cohort studies

Evidence from randomised trials of antihypertensive drugs and the INTERSALT study

Underlying cause of hospitalisation (2018)

Stratified by age and sex; adjusted for regression dilution and total blood cholesterol and, where available, lipid fractions (HDL and non-HDL cholesterol), diabetes, weight, alcohol consumption, and smoking at baseline

Adjusted for age, sex, race or ethnicity, deprivation, smoking, diabetes, inactivity, alcohol, and obesity

There may be health benefits by lowering systolic blood pressure down to $110 \mathrm{~mm} \mathrm{Hg}$ Average cost of hospitalisations per individual costs for CHD and stroke

Primary health, outpatient and informal care and medication costs for $\mathrm{CHD}$ and stroke
Costs were extrapolated to Brazilian settings
Mozaffarian et al. [3]

Micha et al. [23]

Stringhini et al. [24]

Singh et al. [25]

National Hospital Information System (SIH/SUS) [26]

Leal et al. [27]

\section{Summary of evidence regarding the risks of excess sodium consumption}

Excess dietary sodium consumption has been linked to an increased risk of CVD [28]. For CVD, the excess risk appears to be mainly mediated through the deleterious effect of excess sodium consumption on blood pressure (BP) [3]. Our methods for evaluating the causality of sodium reduction on $\mathrm{BP}$ and $\mathrm{BP}$ reduction on CVD have been previously described [3].

\section{Policy effects}

Brazil's Ministry of Health has set voluntary reduction targets with food industries, from 2011 to 2017, based on upper bound sodium concentration targets for 34 food categories [11, 29]. In addition, publicly available data from the Household Budget Survey (POF 20082009) were used to map these 34 food categories through household food acquisition [20] and a 24-h recall dietary questionnaire [21]. These data enabled the 
Repeat until death or end of simulation

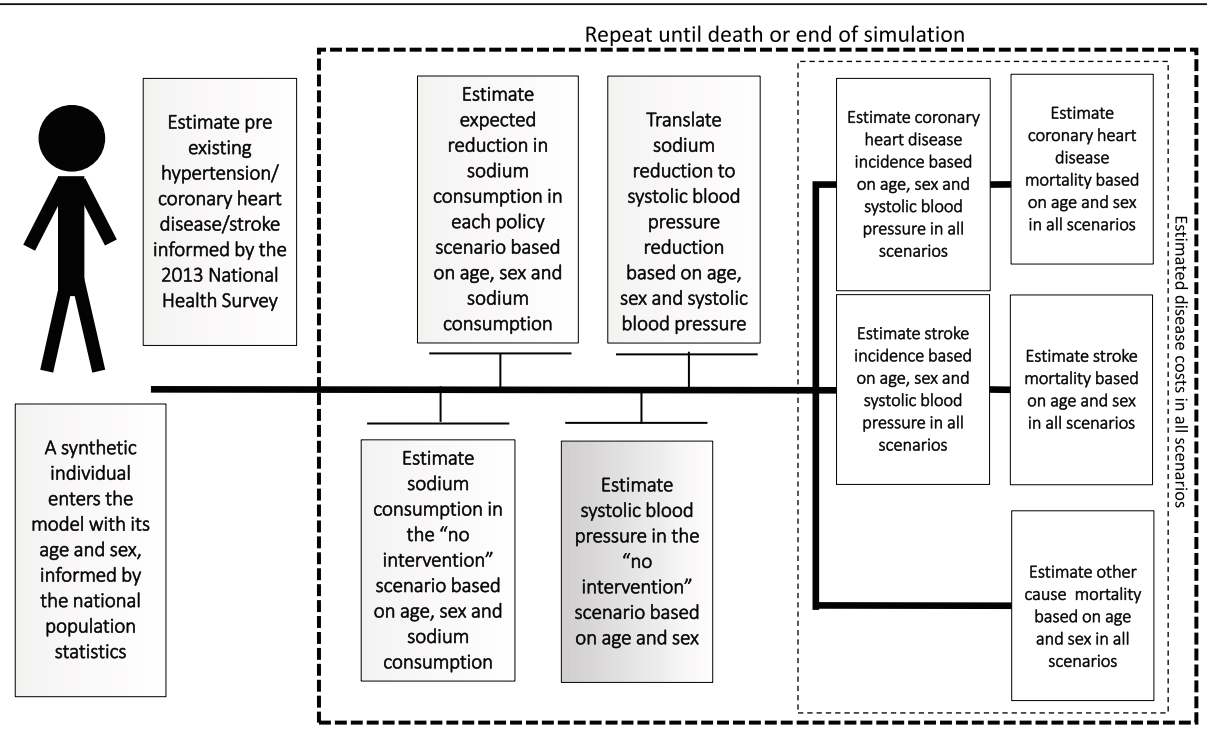

Fig. 1 Simplified structure of the Brazil IMPACT Sodium Policy Model

model to estimate the potential impact of the modelled policies on every synthetic individual based on their age, sex, and sodium consumption in the no intervention baseline scenario. The model then used the estimated reduction in sodium consumption of the synthetic individuals to calculate the effect upon their SBP using a published meta-regression equation [3].

We assumed that reformulation of food products would adjust sodium content to targets until 2017 and that this would lead to an immediate change in sodium intake in synthetic individuals according to the level of reformulation. We also assumed that the reformulated products would, after that, sustain their sodium concentration.

Although changes in sodium intake influence SBP within weeks $[3,30]$, we conservatively assumed a median duration of 5 years from a change in SBP to the health outcomes of CVD cases and CVD deaths.

\section{Modelling of food composition and sodium intake changes}

We have considered changes in food composition from the voluntary sodium targets using data from official national food labelling surveys in 2013 and 2017: the baseline targets and the most recent documented official monitoring, respectively [12]. In addition, changes in sodium intake were modelled using microdata from the 2002-2003 and 2008-2009 Brazilian Household Budget Survey. We assumed that the average food consumption and use of table salt in the population remained constant from 2011 to 2017 and that sodium content was reduced for the targeted food categories only by industries that have voluntarily committed to the national sodium targets (which correspond to a 70\% market share in the country).
We used the publicly available data from the Household Budget Surveys (POF) of 2002-2003 [31] and 2008-2009 [20] in order to estimate the changes in sources of dietary sodium (non-industrial and industrial sources) during the period between both surveys. We projected the continuity of the replacement of discretionary salt (table salt) by processed and ultra-processed foods (representing the other sodium sources), assuming that the replacement would continue at the same rate in the future.

\section{Model outputs}

The model generates the total numbers of relevant events and reported case-years (CHD and stroke) and deaths prevented or postponed (CHD or stroke or other) for each scenario. We present the results for Brazilian adults aged 30 to 79 years from 2011 to 2032 (simulation horizon of 20 years), rounded to 2 significant digits. For simplicity, we used the term "cases prevented or postponed" to express case-years prevented or postponed.

\section{Medical costs analyses}

The CHD and stroke hospitalisation costs to the Brazilian National Health System (SUS-Sistema Único de Saúde) were obtained from the publicly available tables from the Hospital Information System-SIH-SUS [26]. There were no readily available Brazil-specific data for the informal care costs; therefore, we used estimates for these costs from a study on European Union (EU) countries [27]. Cost savings to the health system and the population were estimated considering the $\mathrm{CHD}$ and stroke cases prevented or postponed and the average costs for a person-year living with these diseases. Costs were collected in Brazilian Reals ( $R$ \$) and subsequently 
converted to US dollars (US\$), at an exchange rate of US $\$ 1=\mathrm{R} \$ 3.876$, current as of December 31, 2018, as reported by the Central Bank of Brazil, and all costs and were discounted at a $3 \%$ annual rate.

\section{Sensitivity analyses and uncertainty analyses}

We performed probabilistic sensitivity analyses using a second-order Monte Carlo approach for estimating the uncertainty of different model parameters and population heterogeneity to be propagated to the outputs [32]. Uncertainty was based on sources of the sampling errors of baseline sodium intake, baseline SBP, and the relative risk of CHD and stroke based on SBP, the uncertainties around the lowest sodium and SBP exposures below which no excess risk is observed, around the effect of sodium on SBP, around the lag between SBP changes and CVD risk changes, around the true incidence of $\mathrm{CHD}$ and stroke, and the uncertainty of mortality forecasts. The output distributions produced through the Monte Carlo approach were summarised by reporting the medians and $95 \%$ uncertainty intervals (UIs) using the $2.5 \%$ and $97.5 \%$ percentiles of the output distribution.

\section{Results}

\section{Health-related outcomes}

The modelled results suggest that Brazil's recent voluntary sodium reduction policies have led to a $0.1 \mathrm{~g} /$ day of sodium decline in sodium consumption $(0.25 \mathrm{~g} /$ day salt $)$ from 2011 to 2017 (Fig. 2). If that $0.1 \mathrm{~g} /$ day sodium reduction continues, it could reduce median SBP from $127.7 \mathrm{mmHg}$ (95\% UI: 127.6 to 127.8 ) in the baseline scenario to $127.5 \mathrm{mmHg}$ (95\% UI: 127.4 to 127.6 ) in the reformulation scenario by 2032. Furthermore, it could prevent or postpone approximately 2500 CVD deaths (95\% UI: -900 to 11,000$)$ and some 180,000 CVD cases (95\% UI: 45,000 to 430,000 ), as well as 12,000 deaths

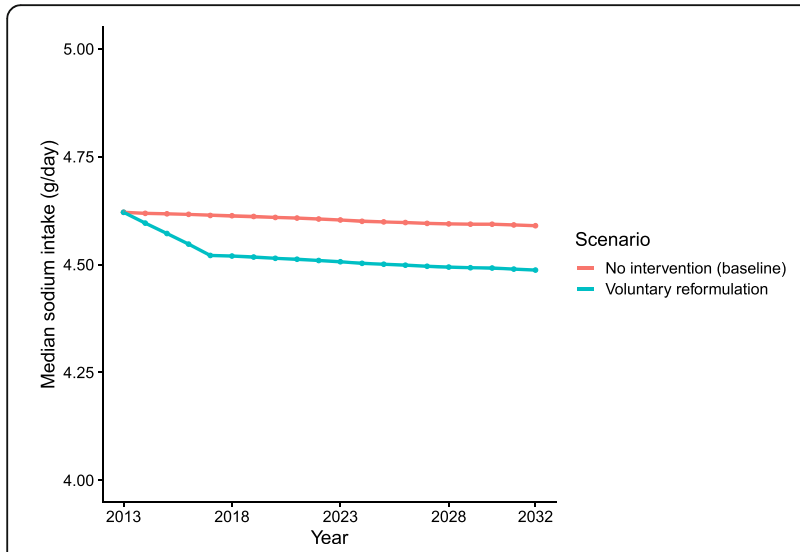

Fig. 2 Median daily sodium consumption by year for the two scenarios. Note that the $y$ axis does not start from 0 from other hypertension-related causes (95\% UI: 3600 to 22,000), from 2013 to 2032 (Table 2).

The health benefits of sodium reduction, especially in reducing $\mathrm{CHD}$, were larger in men than women, reflecting men's higher sodium consumption and higher $\mathrm{CHD}$ and stroke burden. In total, during the 20-year time period from 2013 to 2032, the voluntary sodium targets could prevent or postpone approximately 110,000 CVD cases (95\% UI: 28,000 to 260,000 ) in men and some 70,000 cases in women (95\% UI: 16,000 to 170,000 ), and approximately 1400 fewer CVD deaths in men (95\% UI: -500 to 4100$)$ and 1200 fewer deaths in women $(-500$ to 4800$)$.

Almost two-thirds of the CVD cases and CVD deaths that would be prevented or postponed by this policy between 2013 and 2032 would be in people aged 50 to 69 years (Appendix).

\section{Costs of CHD and stroke}

From the public healthcare perspective, the voluntary targets for sodium could result in a net saving of approximately US\$ 290 million (95\% UI: US\$ 71 to 690 million) in cumulative hospitalisation, primary health, outpatient, pharmaceutical, and informal care costs, over the 20 years. Most of the savings would be related to CHD ( 75\%) rather than stroke.

The US\$ 290 million estimated savings through the continuity of the voluntary sodium targets would come from (Table 3):

a) Approximately US\$220 million savings (95\% UI: US\$ 54 to 520 million) related to reduced CHD and stroke treatment costs to the Brazilian National Health System.

b) Approximately US\$ 70 million (95\% UI: US\$ 17 to170 million) savings in informal care costs.

\section{Discussion}

We have identified potentially large future health and economic benefits if Brazil were to continue the voluntary sodium targets first set in 2011. We used a previously validated microsimulation approach to create a close-to-reality synthetic population (IMPACT $_{\text {NCD-BR }}$ model) for the Brazilian population. Our analysis suggests that continuing the voluntary targets could substantially decrease the CVD burden while also offering considerable cost savings to the public healthcare system and individuals.

However, despite the estimated impacts of the implemented voluntary reformulation, mean sodium intake in Brazil remains well above national targets and WHO recommendations. Hence, there are substantial health and economic opportunity costs of inaction, and despite contributing to the reduction of CVD burden, the 
Table 2 Health-related model estimates over a 20-year simulation period, from 2013 to 2032, for Brazilian adults aged over 30 years. Brackets contain 95\% uncertainty intervals

\begin{tabular}{|c|c|c|c|c|}
\hline Outcome & Men & Women & Persons & $\begin{array}{l}\text { As percentage of } \\
\text { total cases/deaths }\end{array}$ \\
\hline CHD cases prevented or postponed & $67,000(17,000$ to 160,000$)$ & $31,000(6000$ to 78,000$)$ & $98,000(23,000$ to 240,000$)$ & $0.072 \%(0.030$ to $0.15 \%)$ \\
\hline Stroke cases prevented or postponed & $45,000(11,000$ to 100,000$)$ & $39,000(10,000$ to 89,000$)$ & $84,000(22,000$ to 190,000$)$ & $0.14 \%$ (0.068 to $0.23 \%)$ \\
\hline CHD deaths prevented or postponed & $700(-200$ to 900$)$ & $500(-200$ to 2000$)$ & $1200(-500$ to 5000$)$ & $0.064 \%$ (0.000 to $0.15 \%)$ \\
\hline Stroke deaths prevented or postponed & $700(-200$ to 3000$)$ & 700 (-200 to 2800$)$ & $1400(-500$ to 6000$)$ & $0.12 \%$ (0.039 to $0.23 \%)$ \\
\hline $\begin{array}{l}\text { Non-CVD deaths prevented or } \\
\text { postponed }\end{array}$ & $6900(2300$ to 13,000$)$ & 4600 (1400 to 9200) & $12,000$ (3700 to 22,000$)$ & $0.069 \%(0.041$ to $0.11 \%)$ \\
\hline All deaths prevented or postponed & $8300(1800$ to 19,000$)$ & $5800(900$ to 14,000$)$ & $14,000(2700$ to 33,000$)$ & $0.073 \%$ (0.045 to $0.11 \%)$ \\
\hline
\end{tabular}

existing voluntary targets on processed and ultraprocessed foods could be more stringent. Achieving the WHO recommended targets will require a more effective comprehensive strategy, including reformulation, to promote more significant sodium reduction through the whole spectrum of dietary sodium sources in the Brazilian population.

When compared to existing regional and global benchmarks for sodium reduction, Brazil can expect to materialise further benefits by optimising its sodium reduction strategy [29, 33, 34]. The estimated 0.1 -g reduction in daily sodium consumption from 2011 to 2017 achieved by Brazil's voluntary targets has been modest compared with some other countries. A systematic review of 70 papers concluded that multi-component strategies involving both upstream and downstream interventions generally achieved the most considerable reductions in sodium consumption across an entire population, most notably $1.6 \mathrm{~g} /$ day in Finland and Japan, $1.2 \mathrm{~g} /$ day in Turkey, and $0.52 \mathrm{~g} /$ day recently in the UK [9]. Mandatory reformulation alone could achieve a reduction averaging around $0.58 \mathrm{~g} /$ day (three separate studies), followed by voluntary reformulation $(-0.32 \mathrm{~g} /$ day $)$, school interventions $(-0.28 \mathrm{~g} /$ day $)$, short-term dietary advice $(-0.24 \mathrm{~g} /$ day), and nutrition labelling $(-0.16 \mathrm{~g} /$ day $)$. Tax and community-based counselling could each typically reduce sodium intake by $0.12 \mathrm{~g} / \mathrm{day}$, while even smaller population benefits were derived from health education media campaigns $(-0.04 \mathrm{~g} /$ day $)$. Although long-term dietary advice could achieve a $-0.8 \mathrm{~g} /$ day reduction under optimal research trial conditions, smaller reductions might be anticipated in unselected individuals [9]. Furthermore, the burden of disease attributable to excessive dietary sodium remains large, with almost 30,000 avoidable CHD and stroke deaths annually [6].

The voluntary targets reduced the average sodium consumption by $0.1 \mathrm{~g} /$ day of sodium $(0.25 \mathrm{~g} /$ day salt) between 2013 and 2017 (a $25 \mathrm{mg} /$ day reduction in sodium every year), a reduction of just $2 \%$. By contrast, the UK achieved an average annual reduction of $80 \mathrm{mg} /$ day among men and $50 \mathrm{mg} /$ day among women [14] between 2003 and 2010. However, in high-income countries such as the UK, some $80 \%$ of dietary sodium comes from processed and ultra-processed foods, compared with only about $35 \%$ in Brazil, whereas over $55 \%$ comes from added table salt $[7,20]$.

The Brazilian voluntary sodium targets have resulted in a gradual sodium reduction to avoid noticeable changes in the taste of foods and allow industries to develop new technologies to reduce or replace sodium

Table 3 Impact inventory and cost analysis of CVD-related model outputs for individuals aged 30 to 79 years, assessed cumulatively over the 20-year simulation period from 2013 to 2032 (US\$ millions, except when percentages). Brackets contain 95\% uncertainty intervals

\begin{tabular}{|c|c|c|c|c|}
\hline Outcome & Men & Women & Persons & As percentage of total costs \\
\hline Change in total health-related costs & 190 (48 to 440) & 100 (23 to 250$)$ & 290 (71 to 690) & $0.094 \%$ (0.055 to $0.17 \%)$ \\
\hline Total medical costs to SUS & 140 (36 to 330$)$ & $78(17$ to 190$)$ & 220 (54 to 530$)$ & As above \\
\hline Total informal care costs & $46(12$ to 110$)$ & 25 (6 to 61$)$ & $71(17$ to 170$)$ & As above \\
\hline Total CHD-related costs & 150 (38 to 350$)$ & 70 (14 to 180$)$ & 220 (52 to 530$)$ & $0.072 \%(0.030$ to $0.15 \%)$ \\
\hline CHD medical costs to SUS & 120 (29 to 270$)$ & $54(11$ to 130$)$ & 170 (40 to 400$)$ & As above \\
\hline Informal care CHD costs & 36 (9 to 84 ) & 17 (3 to 42 ) & 52 (12 to 130$)$ & As above \\
\hline Total stroke-related costs & 38 (10 to 86$)$ & 33 (9 to 76 ) & $72(19$ to 160$)$ & $0.14 \%$ (0.068 to $0.23 \%)$ \\
\hline Stroke medical costs to SUS & 28 (7 to 64$)$ & 25 (7 to 56$)$ & 53 (14 to 120$)$ & As above \\
\hline Informal care stroke costs & 10 (3 to 22 ) & $9(2$ to 20$)$ & 19 (5 to 42$)$ & As above \\
\hline
\end{tabular}


[35, 36]. Gradual reductions are unlikely to result in compensatory behaviours as adding more table salt to foods or while cooking [37, 38], while large reductions in a short period may trigger rejection or compensatory behaviour by consumers [39].

In 2018, the attributable costs of hypertension to the Brazilian National Health System reached approximately US\$ 525 million/year [40], and in 2013, it was estimated that some US\$ 100 million/year in public hospitalisations could be saved if sodium consumption were reduced to $2 \mathrm{~g} /$ day in Brazil [41].

This study is focused solely on measuring industrial sodium. This will become increasingly important given the increasing contribution of ultra-processed foods in diets. Food reformulation and other regulatory strategies will, therefore, become essential for improving the food environment by providing healthier food options [9].

Furthermore, reducing future population sodium intake in the Brazilian context will depend on strengthening industry action on sodium and improving strategies to modify population behaviour concerning discretionary (non-industrial) salt use. Thus, the Brazilian Dietary Guidelines emphasise the importance of unprocessed and minimally processed foods as the foundation of diets and conscious use of culinary ingredients like salt.

\section{Strengths and limitations of this study}

The IMPACT $\mathrm{T}_{\mathrm{NCD}}$ microsimulation framework has been extensively validated and replicated in different countries $[13,15]$. This is the first IMPACT family microsimulation model adapted to a Latin American country and represents a big step forward for using models to inform policy in the region. The study's strengths also include the use of representative population data and suitable effect sizes from meta-analyses.

This study also has potential limitations. First, the model's effect estimates are based on interventional and prospective observational studies and may retain possible biases and confounding factors. However, the etiological effects of dietary changes were estimated from meta-analyses with confirmatory validity analyses, including from randomised clinical trials. Second, the estimated benefits from the model may be conservative and underestimate the full health and economic health gains from sodium reformulation, as (1) the counterfactual scenario assumed that the participation of processed and ultra-processed foods in sodium intake would not change into the future; (2) the model only evaluated diseases mediated through BP, while decreasing sodium consumption could have beneficial effects upon other health burdens such as gastric cancer [42]; (3) it was assumed a median duration of 5 years from changes in SBP to CVD risk; (4) only the first cardiovascular episode was considered. Therefore, only primary prevention benefits were quantified; and (5) food reformulation by industries might additionally increase potassium intake through substitution of $\mathrm{NaCl}$ with $\mathrm{KCl}$ [43], which potential beneficial effect was not included in the model. Third, informal costs were based on evidence from European countries and, therefore, might not represent Brazil's informal care costs. Finally, medical costs from the private sector, which covers $30 \%$ of the Brazilian population, were not included in the economic estimates, which will therefore be conservative.

\section{Conclusions}

Our findings suggest that the voluntary sodium reduction targets for processed and ultra-processed foods in Brazil could generate health benefits to the population and cost savings to the National Health System and informal health treatment cost. Nevertheless, to achieve more substantial sodium reduction and its consequent health and economic impacts, lower sodium targets must be implemented across all food industries. Other dietary sources of sodium must also be tackled, primarily through food-based dietary guidelines and comprehensive approaches to healthy diets. The potential health and economic benefits could be substantial.

\section{Abbreviations}

BP: Blood pressure; CHD: Coronary heart disease; CVD: Cardiovascular disease; DALYs: Disability-adjusted life-years; NCD: Non-communicable disease; PNS: National Health Survey; POF: Household Budget Survey; SBP: Systolic blood pressure; SIH-SUS: Hospital Information System; SIM: Mortality Information System; SUS: Brazilian National Health System; UI: Uncertainty interval; WHO: World Health Organization

\section{Supplementary Information}

The online version contains supplementary material available at https://doi. org/10.1186/s12916-021-02099-x.

Additional file 1: High-level description of the $I_{M P A C T} T_{N C D-B R}$ model. Figure 1. A logical framework for the IMPACT ${ }_{N C D-B R}$ model. Figure 2. Coronary heart disease mortality by sex. Observed versus modelled number of deaths. Figure 3. Stroke mortality by sex. Observed versus modelled number of deaths. Figure 4. Other (non-coronary heart disease, non-stroke) mortality by sex. Observed versus modelled number of deaths. Figure 5. Population size by sex. Observed versus modelled

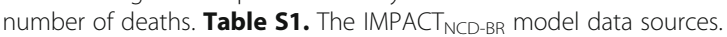
Table S2. Key modelling assumptions and limitations. Table S3. Food categories in the Brazilian voluntary agreements and their mean sodium content at the baseline of negotiations and in 2017 (mg/100g). Table S4. Sodium intake by age and sex groups and by dietary sodium sources at baseline (POF 2008-2009 survey). Table S5. Estimated sodium intake by age and sex groups and by dietary sodium sources considering food reformulation caused by the Brazilian voluntary target scenarios (2017).

Table S6. Health-related model estimates over the 20-year simulation period from 2013 to 2032 for Brazilian adults age 30 to 79 years by sex $[3,4,7,11-15,18,19,24,26,27,29,32,44-81]$.

\section{Acknowledgements}

Not applicable.

Authors' contributions

EAFN and CK conceived the idea and contributed to the design of the work. EAFN and CK contributed to the acquisition, analysis, or interpretation of the 
data for the work. EAFN drafted the manuscript. EAFN, JPs, BC, MGC, SC, MOF, PCJ, and CK critically revised the manuscript. All authors read and approved the final manuscript.

\section{Funding}

This article was possible due to technical cooperation between the researchers and was partially funded by a research grant from the IDRC (International Research Development Centre of Canada), project \#108167, "Scaling Up and Evaluating Salt Reduction Policies and Programs in Latin American Countries", and by the University of Liverpool. The founding sponsors had no role in the study's design; in the collection, analyses, or interpretation of data; in the writing of the manuscript; and in the decision to publish the results.

\section{Availability of data and materials}

All relevant data are within the paper, supporting information files, and the GitHub repository (https://github.com/ChristK/IMPACTncd_Br/tree/voluntary_ reformulation). The source code of the model is available at https://github. com/ChristK/IMPACTncd_Br/tree/voluntary_reformulation. All data inputs are available as .csv files in this repository, except the Population, Household Budget and Health Survey for Brazil microdata, which are publicly accessible through the Brazilian Institute of Geography and Statistics (https://www.ibge. gov.br/), and the hospitalisation and mortality data, which is also publicly available through the Brazilian National Health System's Department of Informatics (http://tabnet.datasus.gov.br/).

\section{Declarations}

\section{Ethics approval and consent to participate}

Not applicable.

\section{Consent for publication}

Not applicable.

\section{Competing interests}

The authors declare that they have no competing interests.

\section{Author details}

${ }^{1}$ Center for Epidemiological Research in Nutrition and Public Health, University of São Paulo, São Paulo, Brazil. ${ }^{2}$ School of Public Health, Imperial College London, London, UK. ${ }^{3}$ Department of Public Health and Policy, University of Liverpool, Liverpool, UK.

\section{Received: 23 February 2021 Accepted: 17 August 2021}

\section{Published online: 29 September 2021}

\section{References}

1. Afshin A, Sur PJ, Fay KA, Cornaby L, Ferrara G, Salama JS, et al. Health effects of dietary risks in 195 countries, 1990-2017: a systematic analysis for the Global Burden of Disease Study 2017. Lancet. 2019;393(19):1958-72 https:// doi.org/10.1016/S0140-6736(19)30041-8.

2. Ministério da Saúde. Saúde Brasil 2018 - Uma análise da situação de saúde e das doenças e agravos crônicos: desafios e perspectivas. Brasília: Ministério da Saúde, Brasil; 2019. 424. http://bvsms.saude.gov.br/bvs/publicacoes/sa ude_brasil_2018_analise_situacao_saude_doencas_agravos_cronicos_desa fios_perspectivas.pdf

3. Mozaffarian D, Fahimi S, Singh GM, Micha R, Khatibzadeh S, Engell RE, et al. Global sodium consumption and death from cardiovascular causes. N Engl J Med. 2014;371(7):624-34 https://doi.org/10.1056/NEJMoa1304127.

4. World Health Organization (WHO). Guideline: Sodium intake for adults and children. World Health Organization. 2012. 56 p. https://www.who.int/ nutrition/publications/guidelines/sodium_intake_printversion.pdf

5. Mill JG, Malta DC, Machado ÍE, Pate A, Pereira CA, Jaime PC, et al. Estimativa do consumo de sal pela população brasileira: resultado da Pesquisa Nacional de Saúde 2013. Rev Bras Epidemiol. 2019;22(suppl 2):E190009. http://www.scielo.br/pdf/rbepid/v22s2/1980-5497-rbepid-22-s2-e190009supl-2.pdf

6. Nilson EAF, Metzler AB, Labonte M-E, Jaime PC. Modelling the effect of compliance with WHO salt recommendations on cardiovascular disease mortality and costs in Brazil. PLoS One. 2020;15(7):e0235514. https://doi. org/10.1371/journal.pone.0235514
7. Sarno F, Claro RM, Levy RB, Bandoni DH, Monteiro CA. Estimated sodium intake for the Brazilian population, 2008-2009. Rev Saude Publica. 2013;47(3): 517-78.

8. IBGE. Pesquisa de Orçamentos Familiares: 2008-2009: Análise do Consumo Alimentar Pessoal no Brasil. Estatística IB de G e, editor. Rio de Janeiro; 2011.

9. Hyseni L, Elliot-Green A, Lloyd-Williams F, Kypridemos C, O'Flaherty M, McGill R, et al. Systematic review of dietary salt reduction policies: Evidence for an effectiveness hierarchy? PLoS One. 2017;12(5):e0177535 https://doi. org/10.1371/journal.pone.0177535.

10. Ministério da Saúde. Dietary Guidelines for the Brazilian Population. Brasília: Ministry of Health of Brazil; 2014. 80. http://bvsms.saude.gov.br/bvs/publica coes/guia_alimentar_populacao_brasileira_2ed.pdf

11. Nilson EAF, Jaime PC, De Oliveira Resende D. Initiatives developed in Brazil to reduce sodium content of processed foods. Rev Panam Salud Publica/ Pan Am J Public Heal. 2012;32(4):287-92. https://www.scielosp.org/article/ rpsp/2012.v32n4/287-292/. https://doi.org/10.1590/S1020-49892012001 000007.

12. Nilson EAF, Spaniol AM, Gonçalves VSS, Moura I, Silva SA, L'Abbé M, et al. Sodium reduction in processed foods in Brazil: analysis of food categories and voluntary targets from 2011 to 2017. Nutrients. 2017;9(7):E742 https:// doi.org/10.3390/nu9070742.

13. Kypridemos C, Guzman-Castillo M, Hyseni L, Hickey GL, Bandosz P, Buchan I, et al. Estimated reductions in cardiovascular and gastric cancer disease burden through salt policies in England: An IMPACT NCD microsimulation study. BMJ Open. 2017;7(1):e013791. https://doi.org/10.1136/bmjopen-2016013791

14. Laverty AA, Kypridemos C, Seferidi P, Vamos E, Pearson-Stuttard J, Collins B, et al. Quantifying the impact of the Public Health Responsibility Deal on salt intake, cardiovascular disease and gastric cancer burdens: interrupted time series and microsimulation study. J Epidemiol Community Health. 2018; 73(9):881-7 https://doi.org/10.1136/jech-2018-211749.

15. Pearson-Stuttard J, Kypridemos C, Collins B, Mozaffarian D, Huang Y, Bandosz P, et al. Estimating the health and economic effects of the proposed US Food and Drug Administration voluntary sodium reformulation: Microsimulation cost-effectiveness analysis. PLoS Med. 2018; 15(4):e1002551. https://doi.org/10.1371/journal.pmed.1002551

16. Collins B, Kypridemos C, Pearson-Stuttard J, Huang Y, Bandosz P, Wilde P, et al. FDA sodium reduction targets and the food industry: are there incentives to reformulate? Microsimulation Cost-Effectiveness Analysis. Milbank Q. 2019;97(3):858-80 https://doi.org/10.1111/1468-0009.12402.

17. IBGE. Projeção da população do Brasil e das Unidades da Federaçã. Projeção da população do Brasil e das Unidades da Federaçã. 2019. https://www. ibge.gov.br/apps/populacao/projecao/

18. IBGE. Brazilian Population Estimates. 2017. https://www.ibge.gov.br/en/sta tistics/social/population/18448-population-estimates.html?=\&t=o-que-e

19. Ministério da Saúde. SIM - Mortality Information System. 2017. http://tabnet. datasus.gov.br/cgi/deftohtm.exe?sim/cnv/obt10uf.def

20. IBGE. Aquisição Alimentar Domiciliar Per Capita - Pesquisa de Orçamentos Familiares - POF 2008-2009. IBGE - Instituto Brasileiro de Geografia e Estatistica; 2010. https://biblioteca.ibge.gov.br/visualizacao/livros/liv47307.pdf

21. IBGE. Consumo Alimentar Pessoal - Pesquisa de Orçamentos Familiares POF 2008-2009. IBGE - Instituto Brasileiro de Geografia e Estatistica; 2011. 150. https://biblioteca.ibge.gov.br/visualizacao/livros/liv50063.pdf

22. IBGE. Pesquisa Nacional de Saúde - PNS 2013. Pesquisa Nacional de Saúde PNS 2013. 2014. https://www.ibge.gov.br/estatisticas/sociais/saude/9160pesquisa-nacional-de-saude.html?=\&t=microdados

23. Micha R, Peñalvo JL, Cudhea F, Imamura F, Rehm CD, Mozaffarian D. Association between dietary factors and mortality from heart disease, stroke, and type 2 diabetes in the United States. JAMA - J Am Med Assoc. 2017; 317(9):912-24 https://doi.org/10.1001/jama.2017.0947.

24. Stringhini $S$, Carmeli $C$, Jokela M, Avendaño M, Muennig P, Guida F, et al. Socioeconomic status and the $25 \times 25$ risk factors as determinants of premature mortality: a multicohort study and meta-analysis of 1.7 million men and women. Lancet. 2017;389(10075):1229-37 https://doi.org/10.1016/ S0140-6736(16)32380-7.

25. Singh GM, Danaei G, Farzadfar F, Stevens GA, Woodward M, Wormser D, et al. The age-specific quantitative effects of metabolic risk factors on cardiovascular diseases and diabetes: a pooled analysis. PLoS One. 2013;8(7): e65174 https://doi.org/10.1371/journal.pone.0065174.

26. Ministério da Saúde. SIH-SUS - Hospital Information System. 2017. http://ta bnet.datasus.gov.br/cgi/deftohtm.exe?sih/cnv/niuf.def 
27. Leal J, Luengo-Fernández R, Gray A, Petersen S, Rayner M. Economic burden of cardiovascular diseases in the enlarged European Union. Eur Heart J. 2006;27(13):1610-9 https://doi.org/10.1093/eurheartj/ehi733.

28. Strazzullo P, D’Elia L, Kandala NB, Cappuccio FP. Salt intake, stroke, and cardiovascular disease: meta-analysis of prospective studies. BMJ. 2009;339: b4567. https://doi.org/10.1136/bmj.b4567

29. Nilson EAF, Spaniol AM, Gonçalves VSS, Oliveira ML, Campbell N, L'Abbé M, et al. The impact of voluntary targets on the sodium content of processed foods in Brazil, 2011-2013. J Clin Hypertens. 2017;19(10):939-45 https://doi. org/10.1111/jch.13044.

30. Aburto NJ, Ziolkovska A, Hooper L, Elliott P, Cappuccio FP, Meerpohl JJ. Effect of lower sodium intake on health: systematic review and metaanalyses. BMJ. 2013;346:f1326. https://doi.org/10.1136/bmj.f1326

31. IBGE. Aquisição alimentar domiciliar per capita: Brasil e Grandes Regiões. 2004. 251 p. https://servicodados.ibge.gov.br/Download/Download.a shx?http=1\&u=biblioteca.ibge.gov.br/visualizacao/livros/liv66830.pdf

32. Koerkamp BG, Stijnen T, Weinstein MC, Hunink MGM. The combined analysis of uncertainty and patient heterogeneity in medical decision models. Med Decis Mak. 2011;31(4):650-61 https://doi.org/10.1177/0272 989X10381282.

33. Campbell N, Legowski B, Legetic B, Nilson E, L'Abbé M. Inaugural maximum values for sodium in processed food products in the Americas. J Clin Hypertens. 2015;17(8):611-3 https://doi.org/10.1111/jch.12553.

34. World Health Organization (WHO). WHO global sodium benchmarks for different food categories. Geneva, Switzerland; 2021.32 p. https://www.who. int/publications/i/item/9789240025097

35. Levings $J L$, Cogswell ME, Gunn JP. Are reductions in population sodium intake achievable? Nutrients. 2014;6(10):4354-61 https://doi.org/10.3390/ nu6104354.

36. Dötsch M, Busch J, Batenburg M, Liem G, Tareilus E, Mueller R, et al. Strategies to reduce sodium consumption: a food industry perspective. Crit Rev Food Sci Nutr. 2009;258(22):3275-8 https://doi.org/10.1080/104083 90903044297.

37. Shepherd R, Farleigh CA, Wharf SG. Limited compensation by table salt for reduced salt within a meal. Appetite. 1989;13(3):193-200 https://doi.org/10.1 016/0195-6663(89)90012-3.

38. Beauchamp GK, Bertino M, Engelman K. Failure to compensate decreased dietary sodium with increased table salt usage. JAMA J Am Med Assoc. 1987;258(22):3275-8. https://jamanetwork.com/journals/jama/article-abstra ct/369662. https://doi.org/10.1001/jama.1987.03400220075040.

39. Brockman C. Impact of reduced salt products in the market place. In: Beeren C, Groves K, Titoria PM, editors. Reducing salt in foods. 2nd Editio. Elsevier Ltd; 2019. p. 100-105. https://doi.org/10.1016/B978-0-08-100890-4.00004-4

40. Nilson EAF, Andrade R da CS, Brito DA de, Oliveira ML De. Custos atribuíveis à obesidade, hipertensão e diabetes no Sistema Único de Saúde em 2018. Rev Panam Salud Publica/Pan Am J Public Heal. 2020;44:e32. https://doi. org/10.26633/RPSP.2020.32

41. Nilson EAF, Silva EN da, Jaime PC. Developing and applying a costing tool for hypertension and related cardiovascular disease: attributable costs to salt/sodium consumption. J Clin Hypertens. 2020;00:1-7. https://doi.org/1 $0.1111 /$ jch.13836

42. D'Elia L, Rossi G, Ippolito R, Cappuccio FP, Strazzullo P. Habitual salt intake and risk of gastric cancer: a meta-analysis of prospective studies. Clin Nutr. 2012;31(4):489-98 https://doi.org/10.1016/j.clnu.2012.01.003.

43. Micha R, Shulkin ML, Peñalvo JL, Khatibzadeh S, Singh GM, Rao M, et al. Etiologic effects and optimal intakes of foods and nutrients for risk of cardiovascular diseases and diabetes: Systematic reviews and meta-analyses from the nutrition and chronic diseases expert group (NutriCoDE). PLoS One. 2017:12(4):e0175149. https://doi.org/10.1371/journal.pone.0175149

44. He FJ, Tan M, Ma Y, MacGregor GA. Salt reduction to prevent hypertension and cardiovascular disease: JACC state-of-the-art review. J Am Coll Cardiol. 2020;75(6):632-47. Available from: https://doi.org/10.1016/j.jacc.2019.11.055

45. Strazzullo P. Compelling evidence for salt-dependence of blood pressure from GENSALT. J Hypertens. 2009;27(1):22-23. Available from: https://doi. org/10.1097/HJH.0b013e32831e4277

46. Huang L, Trieu K, Yoshimura S, Neal B, Woodward M, Campbell NRC, et al. Effect of dose and duration of reduction in dietary sodium on blood pressure levels: systematic review and meta-analysis of randomised trials. BMJ. 2020;368:m315. Available from: https://doi.org/10.1136/bmj.m315

47. Mente A, O'Donnell M, Rangarajan S, Dagenais G, Lear S, McQueen M, et al. Associations of urinary sodium excretion with cardiovascular events in individuals with and without hypertension: a pooled analysis of data from four studies. Lancet. 2016;388(10043):465-75. Available from: https://doi. org/10.1016/S0140-6736(16)30467-6

48. O'Donnell M, Mente A, Rangarajan S, McQueen MJ, Wang X, Liu L, et al. Urinary sodium and potassium excretion, mortality, and cardiovascular events. N Engl J Med. 2014;371(7):612-23. Available from: https://doi.org/1 0.1056/NEJMoa1311889

49. Graudal NA, Hubeck-Graudal T, Jurgens G. Effects of low sodium diet versus high sodium diet on blood pressure, renin, aldosterone, catecholamines, cholesterol, and triglyceride. Cochrane Database Syst Rev. 2017:4:CD004022. Available from: https://doi.org/10.1002/14651858.CD004022.pub4

50. He FJ, Ma Y, Campbell NRC, MacGregor GA, Cogswell ME, Cook NR. Formulas to estimate dietary sodium intake from spot urine alter sodiummortality relationship. Hypertension. 2019;74(3):572-80. https://doi.org/10.11 61/HYPERTENSIONAHA.119.13117.

51. Cook NR, He FJ, MacGregor GA, Niels Graudal. Sodium and health—concordance and controversy. BMJ. 2020;369:m2440. Available from: https://www.bmj.com/content/bmj/369/bmj.m2440.full.pdf

52. Campbell NRC, Lackland DT, Niebylski ML, Nilsson PM. Is reducing dietary sodium controversial? Is it the conduct of studies with flawed research methods that is controversial? A perspective from the World Hypertension League Executive Committee. J Clin Hypertens. 2015;17(2):85-6. Available from: https://doi.org/10.1111/jch.12437

53. He FJ, Brown M, Tan M, MacGregor GA. Reducing population salt intake - an update on latest evidence and global action. J Clin Hypertens. 2019;21(July):1596-601. Available from: https://doi.org/10.1111/jch.13664

54. EFSA Panel on Nutrition Novel Foods and Food Allergens (NDA). Dietary reference values for sodium. EFSA J. 2019;17(9):1-191. Available from: https://efsa.onlinelibrary.wiley.com/doi/epdf/10.2903/j.efsa.2019.5778

55. National Academies of Sciences Engineering and Medicine. Dietary Reference Intakes for Sodium and Potassium. Stallings VA, Harrison M, Oria M, editors. Dietary Reference Intakes for Sodium and Potassium. Washington, DC: The National Academies Press; 2019.578 p. Available from: http://nationalacademies.org/hmd/Reports/2019/dietary-reference-intakessodium-potassium.aspx

56. He FJ, Li J, MacGregor GA. Effect of longer term modest salt reduction on blood pressure: Cochrane systematic review and meta-analysis of randomised trials. BMJ. 2013;346:f1325. Available from: https://doi.org/10.113 6/bmj.f1325

57. Lawes C, Vander Hoorn S, Law M, P E, MacMahon S, A. R. Chapter 6: high blood pressure. In: Ezzati M, Lopez A, Rodgers A, Murray C, editors. Comparative quantification of health risks. Geneva: World Health Organization (WHO); 2004. Available from: http://www.who.int/publications/ cra/en/

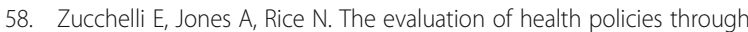
microsimulation methods. Int J Microsimulation. 2010;5(1):02-20 Available from: https://www.microsimulation.org/IJM/V5_1/1_IJM_5_1_spring_2012_ Zuchelli_Rice_Jones.pdf.

59. IBGE. Pesquisa Nacional de Saúde - PNS 2013. Pesquisa Nacional de Saúde PNS 2013. 2014. Available from: https://www.ibge.gov.br/estatisticas/sociais/ saude/9160-pesquisa-nacional-de-saude.html?=\&t=microdados

60. Stasinopoulos M, Rigby B, Akantziliotou C. Instructions on how to use the gamlss package in R. 2nd ed. 2008. 206. Available from: http://www.gamlss. com/wp-content/uploads/2013/01/gamlss-manual.pdf

61. Suen SC, Goldhaber-Fiebert JD, Basu S. Matching microsimulation risk factor correlations to cross-sectional data: the shortest distance method. Med Decis Mak. 2018:0272989X17741635. Available from: https://doi.org/10/ gc5p36

62. Evans D, Edejer TTT, Chisholm D, Stanciole A. WHO Guide to identifying the economic consequences of disease and injury. Geneva: World Health Organization. Geneva: World Health Organization (WHO); 2009. 136 p. Available from: https://www.who.int/choice/publications/d_economic_impa ct_guide.pdf

63. Capewell S, O'Flaherty M. Rapid mortality falls after risk-factor changes in populations. Lancet, Available from. 2011;378(9793):752-3 https://doi.org/1 0.1016/S0140-6736(10)62302-1.

64. Capewell S, O'Flaherty M. Can dietary changes rapidly decrease cardiovascular mortality rates? Eur Heart J. 2011;32(10):1187-9 Available from: https://doi.org/10.1093/eurheartj/ehr049.

65. Smolina K, Wright FL, Rayner M, Goldacre MJ. Determinants of the decline in mortality from acute myocardial infarction in England between 2002 and 
2010: Linked national database study. BMJ. 2012;344:d8059 Available from: https://doi.org/10.1136/bmj.d8059.

66. Young F, Capewell S, Ford ES, Critchley JA. Coronary mortality declines in the US between 1980 and 2000: quantifying the contributions from primary and secondary prevention. Am J Prev Med. 2010;39(3):228-34. Available from: https://doi.org/10.1016/i.amepre.2010.05.009

67. Unal B, Critchley JA, Capewell S. Explaining the decline in coronary heart disease mortality in England and Wales between 1981 and 2000. Circulation. 2004;109(9):1101-7. Available from: https://doi.org/10.1161/01. CIR.0000118498.35499.B2

68. Ford ES, Ajani UA, Croft JB, Critchley JA, Labarthe DR, Kottke TE, et al. Explaining the decrease in US deaths from coronary disease, 1980-2000. N Engl J Med. 2007;356(23):2388-98 Available from: https://doi.org/10.1056/ NEJMsa053935.

69. Barendregt JJ, van Oortmarssen GJ, Vos T, Murray CJL. A generic model for the assessment of disease epidemiology: the computational basis of DisMod II. Popul Health Metr. 2003; (1):4. Available from: https://doi.org/1 0.1186/1478-7954-1-4

70. Lim SS, Vos T, Flaxman AD, Danaei G, Shibuya K, Adair-Rohani $H$, et al. A comparative risk assessment of burden of disease and injury attributable to 67 risk factors and risk factor clusters in 21 regions, 1990-2010: a systematic analysis for the Global Burden of Disease Study 2010. Lancet. 2012;380(9859):2224-60. Available from: https://dx.doi.org/1 0.1016\%2FS0140-6736(12)61766-8. https://doi.org/10.1016/50140-6736(12 61766-8.

71. Boshuizen HC, Lhachimi SK, van Baal PHM, Hoogenveen RT, Smit HA, Mackenbach JP, et al. The DYNAMO-HIA model: an efficient implementation of a risk factor/chronic disease Markov model for use in Health Impact Assessment (HIA). Demography. 2012;49(4):1259-83. Available from: https:// doi.org/10/f4jzrb. https://doi.org/10.1007/s13524-012-0122-z.

72. Hyndman RJ. Forecasting mortality, fertility, migration and population data. 2017. Available from: http://cran.r-project.org/package=demography

73. Hyndman R, Shahid Ullah M. Robust forecasting of mortality and fertility rates: a functional data approach. Comput Stat Data Anal. 2007;51(10):494256. Available from: https://doi.org/10.1016/j.csda.2006.07.028

74. Hyndman RJ, Booth H, Yasmeen F. Coherent mortality forecasting: the product-ratio method with functional time series models. Demography. 2013;50(1):261-83. Available from: https://doi.org/10.1 007/s13524-012-0145-5

75. Ministério da Saúde. I Termo de Compromisso com a finalidade de estabelecer metas nacionais para a redução do teor de sódio em alimentos processados no Brasil. I Termo de Compromisso com a finalidade de estabelecer metas nacionais para a redução do teor de sódio em alimentos processados no Brasil. 2011. Available from: http://1 89.28.128.100/dab/docs/portaldab/documentos/termo_abia_abip_a bima_abitrigo_2011.pdf

76. Ministério da Saúde. II Termo de Compromisso com a finalidade de estabelecer metas nacionais para a redução do teor de sódio em alimentos processados no Brasil. II Termo de Compromisso com a finalidade de estabelecer metas nacionais para a redução do teor de sódio em alimentos processados no Brasil. 2011. Available from: http://189.28.128.100/dab/docs/ portaldab/documentos/termo_5_dez_2011.pdf

77. Ministério da Saúde. III Termo de Compromisso com a finalidade de estabelecer metas nacionais para a redução do teor de sódio em alimentos processados no Brasil. III Termo de Compromisso com a finalidade de estabelecer metas nacionais para a redução do teor de sódio em alimentos processados no Brasil. 2012 [cited 2012 Aug 10]. Available from: http://189.28.128.100/dab/docs/portaldab/documentos/ termo_6_ago_2012.pdf

78. Ministério da Saúde. IV Termo de Compromisso com a finalidade de estabelecer metas nacionais para a redução do teor de sódio em alimentos processados no Brasil. IV Termo de Compromisso com a finalidade de estabelecer metas nacionais para a redução do teor de sódio em alimentos processados no Brasil. 2013. Available from: http://189.28.128.100/dab/docs/ portaldab/documentos/termo_nov_2013.pdf

79. Ministério da Saúde. I Fase do Monitoramento do Plano Nacional de Redução do Sódio em Alimentos Processados. 2014. Available from: http://1 89.28.128.100/dab/docs/portaldab/documentos/relatorio_de_monitora mento_I_termo_de_compromisso.pdf

80. Ministério da Saúde. II Fase do Monitoramento do Plano Nacional de Redução do Sódio em Alimentos Processados. 2014. Available from: http://1 89.28.128.100/dab/docs/portaldab/documentos/relatorio_de_monitora mento II_termo de compromisso.pdf

81. da Saúde M. III Fase do Monitoramento do Plano Nacional de Redução do Sódio em Alimentos Processados. Brasil: Brasília; 2018. Available from: http://189.28.128.100/dab/docs/portaldab/documentos/promocao/relatorio_ motitoramento_consolidado_17_18.pdf

\section{Publisher's Note}

Springer Nature remains neutral with regard to jurisdictional claims in published maps and institutional affiliations.
Ready to submit your research? Choose BMC and benefit from:

- fast, convenient online submission

- thorough peer review by experienced researchers in your field

- rapid publication on acceptance

- support for research data, including large and complex data types

- gold Open Access which fosters wider collaboration and increased citations

- maximum visibility for your research: over $100 \mathrm{M}$ website views per year

At $\mathrm{BMC}$, research is always in progress.

Learn more biomedcentral.com/submissions 